\title{
Ungulate herbivory on buckbrush in an Arizona ponderosa pine forest
}

\author{
DAVID W. HUFFMAN AND MARGARET M. MOORE
}

Authors are Senior Research Specialist, Ecological Restoration Institute, and Professor, School of Forestry, Northern Arizona University, Flagstaff, Ariz, 86011. Email:David.Huffman@nau.edu

Abstract

Monitoring processes that affect plant population dynamics and determine community structure is central in forest restoration ecology. To study effects of mule deer (Odocoileus hemionus) and elk (Cervus elaphus) on buckbrush (Ceanothus fendleri Gray), we built exclosures around 90 plant-centered plots in 3 ponderosa pine (Pinus ponderosa Laws.) forest restoration management units and compared vegetative and flowering characteristics with unprotected plots for 2 years. On unprotected plots, 69\% of the current-year branches were browsed during the first year and $44 \%$ were browsed the second year. There was no difference in number of aerial stems or current-year branches in the first year, yet stems on protected plots were longer $(24.1 \mathrm{~cm}$; $P<0.01)$ and retained more than 4 times the current-year biomass $\left(1.4 \mathrm{~g} \mathrm{stem}^{-1} ; \mathbf{P}<0.01\right)$ than those on unprotected plots $(12.9$ $\mathrm{cm}$ and $0.3 \mathrm{~g} \mathrm{stem}^{-1}$, respectively). Stem number, length and diameter, number of current-year branches, and current-year biomass on protected plots were all greater $(P<0.01)$ than on unprotected plots in the second year. Stems on protected plots had significantly higher $(P<0.01)$ length-diameter ratios and had fewer current-year branches per unit length $(P<0.05)$ than unprotected stems. Flowering stems were found on significantly $(P<0.05)$ more protected plots $(55 \%)$ than unprotected plots $(8 \%)$ in the second year. Effects of ungulate herbivores on buckbrush size, stem recruitment, morphology, and flowering represent important constraints to early understory development and restoration in this Southwest ponderosa pine forest.

Key Words: ecological restoration, Ceanothus fendleri, stem morphology, flower production, Cervus elaphus, Odocoileus hemionus

It is widely recognized that large mammalian herbivores, through selective grazing and physical disturbance to sites, often play key roles in ecosystems and affect community composition, structure, and development as well as various ecological processes (Anderson and Loucks 1979, Naiman 1988, Augustine and McNaughton 1998). Under episodic or light herbivory, browsed plants may compensate for tissue loss by increasing production of

We thank P. Z. Fulé, A. E. M. Waltz, and 2 anonymous reviewers for insightful comments on this manuscript. Students and staff of the Ecological Restoration Institute at Northern Arizona University provided field support. This project was funded by USFS Rocky Mountain Research Station and Northern Arizona University (School of Forestry), Research Joint Venture Agreement, RMRS99167-RJVA.

Manuscript accepted 26 Aug. 02.

\section{Resumen}

EI monitoreo de procesos que afectan las dinámicas de las poblaciones de plantas y determinan la estructura de la comunidad es un punto central en ecología de restauración de bosques. Para estudiar los efectos del "Mule deer" (Odocoileus hemionus) y el "Alce" (Cervus elaphus) sobre el "Buckbrush" (Ceanothus fendleri Gray), construimos exclusiones alrededor de 90 parcelas con plantas en el centro ubicadas en 3 unidades de manejo de restauración de "Pino ponderosa" (Pinus ponderosa Laws.), y en 2 años comparamos las características vegetativas y de floración con parcelas sin excluir. En las parcelas sin protección el $69 \%$ de las ramas nuevas producidas en el año fueron consumidas y el $44 \%$ consumidas en el segundo año. No hubo diferencias en el número de tallos aéreos o ramas nuevas producidas en el primer año, pero los tallos en las parcelas protegidas fueron mas largos $(24.1 \mathrm{~cm} ; P<0.01)$ y conservaron 4 veces más biomasa nueva $\left(1.4 \mathrm{~g}_{\text {tallo }}{ }^{-1} ; \mathrm{P}<0.01\right)$ que las plantas en las parcelas sin protección $\left(12.9 \mathrm{~cm}\right.$ y $0.3 \mathrm{~g} \mathrm{tallo}^{-1}$, respectivamente). En el segundo año el número de tallos, longitud y diámetro, número de ramas nuevas y la biomasa nueva fueron mayores en las parcelas protegidas que en las no protegidas. Los tallos en las parcelas protegidas tuvieron una relación longitud-diámetro significativamente mayor $(P<0.01)$ y tuvieron menos ramas nuevas por unidad de longitud $(\mathrm{P}<0.05)$ que los tallos sin protección. En el segundo año, se encontró una proporción significativamente mayor de parcelas protegidas $(55 \% ; P<0.05)$ con tallos florales en comparación con las no protegidas $(8 \%)$. Los efectos de los herbívoros ungulados en el tamaño, dinámica de tallos, morfología y floración del "Buckbrush" representa un importante restricción para el desarrollo inicial y restauración las capas bajas de la estructura de este bosque de "Ponderosa pine" del suroeste.

biomass or reproductive structures (Paige and Whitham 1987, Rosenthal and Kotanen 1994, Augustine and McNaughton 1998, Throop and Fay 1999). Intense herbivory can lead to decreased stature and reproductive output, regeneration failure, and population decline (Strohmeyer and Maschinski 1996, Kay 1997, Augustine and Frelich 1998, Augustine and McNaughton 1998 , Suzuki et al. 1999, Opperman and Merenlender 2000). Through direct competition with other herbivores and indirect "knock-on" effects, large herbivores can affect population dynamics and distribution of other members of the food web (Baines et al. 1994, Rooney 2001, Stewart 2001). The array of potential ecosystemlevel consequences makes assessment and monitoring of herbivore impacts particularly important for ecological restoration programs. 
An extraordinary increase in tree density over the last century has led to critical conservation problems in ponderosa pine (Pinus ponderosa Laws.) ecosystems of the southwestern United States (Arnold 1950, Covington and Moore 1994a, 1994b, Kolb et al. 1994, Biondi 1996, Savage et al. 1996, Fulé et al. 1997, Mast et al. 1999). Among other effects, dense forest conditions have reduced forage abundance and habitat quality for wildlife that rely on understory vegetation (Covington and Moore 1994a). In concert with forest structural changes, Rocky Mountain elk (Cervus elaphus nelsoni) were introduced to the region in the early 1900 s to replace the extirpated Merriam's elk (C. e. merriami). Numbers of elk have increased over the last 100 years to around 30,000 animals in Arizona and 40,00050,000 animals in New Mexico (Truett 1996). Although restoration treatments such as thinning small diameter trees and reintroducing low-intensity surface fires have been suggested to restore ecological structure and function to these forests (Kolb et al. 1994, Covington et al. 1997, Moore et al. 1999), research on the impacts of herbivory on plant species' response to restoration thinning is presently lacking.

Buckbrush (Ceanothus fendleri Gray), is a semi-evergreen, nitrogen-fixing shrub common in ponderosa pine forest understories of the Southwest (Story 1974, Conard et al. 1985). As a shrub species in primarily herbaceous communities, buckbrush populations can provide structural heterogeneity in forest understories and enhance ecological diversity. Although buckbrush has been reported as an important browse plant for mule deer (Odocoileus hemionus), and other animals including elk apparently consume its leaves, stems, fruit, and seeds (Urness et al. 1975, Epple 1995, Allen 1996, Huffman 2002), effects of herbivory on buckbrush growth and reproduction have not been studied. Information concerning intensity of wild ungulate herbivory and its effects on important understory species can help land managers interpret trends in community development and better understand processes constraining restoration of ecosystems. Our objectives in this study were to: 1) quantify the effects of large ungulate herbivory on buckbrush vegetative characteristics such as size, production, and morphology; and 2) examine herbivory effects on buckbrush potential reproduction.

\section{Methods}

\section{Study Site}

We conducted our study from 19992000 on the Fort Valley Experimental Forest $\left(35^{\circ} 16^{\prime} \mathrm{N}, 111^{\circ} 41^{\prime} \mathrm{W}\right)$ in Coconino County approximately $10 \mathrm{~km}$ northwest of Flagstaff, Ariz. The area receives around $52 \mathrm{~cm}$ of precipitation annually with a distinct dry period in May and June. Precipitation falls in late summer as rain from monsoonal thunderstorms and in winter as snow. The study area was located from 2,225 to $2,380 \mathrm{~m}$ above mean sea level. Aspect was generally southern and the topography was gentle with average slopes of approximately 5-10\%. Soils are classified as Brolliar clay loams (fine, smectitic, mesic Typic Argiustolls) developed on tertiary basalt parent material and are moderately well drained (Unpublished report, Meurisse).

Overstory vegetation was nearly pure ponderosa pine less than 120-years-old with scattered old-growth trees. Common understory species included grasses Arizona fescue (Festuca arizonica Vasey), mountain muhly (Muhlenbergia montana (Nutt.) A.S. Hitchc.), bottlebrush squirreltail (Elymus elymoides (Raf.) Swezey) and pine dropseed (Blepharoneuron tricholepis (Torr.) Nash); forbs lupine (Lupinus spp.), fleabane (Erigeron spp.), buckwheat (Eriogonum spp.), yarrow (Achillea millifolium L.), and pussytoes (Antennaria spp.); and shrubs buckbrush and woods rose (Rosa woodsii Lindl.). Large mammalian herbivores present on the site included mule deer and elk. Cattle were excluded from the study site.

\section{Experimental Design}

In late winter 1998, tree thinning was initiated on 9 units of 14-16 hectares each on the study site. The thinning from below reduced tree density by $80 \%$ to approximately 111-210 trees per hectare, which were grouped around the spatial locations of presettlement tree structures (see Covington et al. 1997 for restoration guidelines). We selected 3 of these units for our study, each separated by at least 1 kilometer.

In early spring 1999 , we located 60 buckbrush clonal assemblages in each of the 3 units (180 total). The plots were randomized into either protected or unprotected treatments. Circular plots, $1 \mathrm{~m}^{2}$, were established around 1 or more existing stems and contained 1-25 buckbrush stems. Buckbrush is rhizomatous and can expand vegetatively (Vose and White 1987). Sprouting also occurs from a pronounced root crown (Huffman pers. obs.).
Thus, it is not known whether 1 or many clones produced the aerial stems we sampled. Stem assemblages selected were spatially discrete and generally covered an area less than $2 \mathrm{~m}^{2}$. Hereafter, we refer to stem assemblages within plots as "plants". Herbivore exclosures $4 \mathrm{~m}^{2}$ in area and 1.4 $\mathrm{m}$ in height were constructed around plots receiving the protection treatment. Mesh size used for fencing exclosures was $5 \mathrm{x}$ $10 \mathrm{~cm}$. This allowed entry of small mammalian and invertebrate herbivores but excluded large ungulates.

In each of the 2 study years, we collected data on flower production and vegetative characteristics. In June of each year, we examined stems in all plots for production of inflorescences. For stems producing flowers or flower buds, we measured total stem length and basal diameter. We classified stems into 4 relative age groups according to stem base characteristics as follows: Class-1) first-year stems, not suberized, generally supple, gray-green pubescence at stem base; Class-2) bright green, not suberized, previous year's growth of lateral branches present, generally lacked pubescence; Class-3) similar to Class-2 with bark developing in patches at stem base; Class-4) stem bases dark brown to black, fully suberized, bark often furrowed. Although we have observed buckbrush plants on long-term plots at other sites develop similar characteristics over time (Moore pers. obs.), we were not able to confirm actual ages through ring counts or meristem scars. We also counted number of inflorescences on flowering stems. In September, measurements collected for flowering stems were taken for all stems on the plots. Additionally, the number of current-year branches was counted, average length of current-year branches was estimated, and longest current-year branch was measured.

For all stems, biomass, and leaf area (LA) of current-year branches were estimated using predictive relationships developed from separate sampling in the study units. Forty-five to 50 current-year stems were collected from clonal assemblages outside the experimental plots. For biomass determination, current-year stems $(\mathrm{n}=50)$ were measured for length, ovendried $\left(70^{\circ} \mathrm{C}\right.$ for 48 hours), and weighed to the nearest $0.01 \mathrm{~g}$. For leaf area (LA) determination, current-year stems $(n=45)$ were measured for length and leaves were removed and analyzed for 1-sided LA by a video projection system (AgVision ${ }^{\mathrm{TM}}$ ). The equation to predict current-branch biomass was: $L n$ Biomass $=-4.919+$ 1.395(Ln Branch Length) $\left(\mathrm{r}^{2}=0.94, \mathrm{P}<\right.$ 

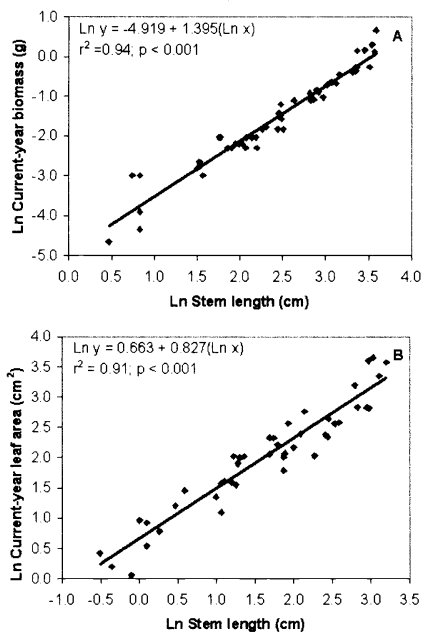

Fig. 1. Relationships used to estimate biomass (A) and leaf area (B) of current-year branches on Ceanothus fendleri plants.

0.001) (Fig. 1a). The equation to predict current-branch LA was: Ln LA $=0.663+$ 0.827 (Ln Branch Length) $\left(r^{2}=0.91, P<\right.$ 0.001) (Fig. 1b).

\section{Data Analyses}

One-way analysis of variance (ANOVA) was used to test for effects of protection on vegetative characteristics of buckbrush plants within study years (1999 and 2000). Overstory unit was included in the ANOVA model as a blocking factor. Paired t-tests were used to test $(\mathrm{P}<0.10)$ between-year differences in vegetative parameters within treatment (protected and unprotected) groups. Data for individual stems (i.e., length, number of currentyear branches, length of current-year branches, biomass and leaf area per stem) were averaged at the plot level and analyses were performed on these values.
Additionally, stem diameter, current year biomass, and current-year leaf area were summed at the plot level and analyzed for treatment differences. Morphological characteristics tested were stem heightdiameter ratio and branchiness. Branchiness was calculated as the number of current-year branches divided by stem length. Data met distribution and variance assumptions for ANOVA tests and were not transformed. In April 2000, 24 of the plots were burned as part of another experiment. These plots were excluded from analysis in year 2000 .

A Mantel-Haenszel test was used to compare $(\mathrm{P}<0.05)$ proportions of unprotected and protected plots with flower-producing stems. Mann-Whitney nonparametric tests were used to analyze $(\mathrm{P}<0.05)$ differences in stem and current-branch number between treatments.

\section{Results}

\section{Plant Size and Current-Year Biomass}

Analysis of pretreatment data indicated no difference in stem length or number of stems between treatments. Stem length averaged $7.6 \mathrm{~cm}(\mathrm{SE}=0.30)$ and number of stems per plot averaged $4.9(\mathrm{SE}=$ 0.31 ).

By the end of the first growing season (1999), 69\% of the current-year branches on unprotected plots had been browsed. Two percent of the new branches inside exclosures had terminal buds removed apparently by invertebrates. We did not observe signs of small rodent herbivory inside exclosures although mesh size permitted rodent access. Herbivory on unprotected plants appeared consistent with browsing from large ungulates; currentyear branches were nipped roughly, often near their bases, and we did not find discarded shoots or leaves that might suggest herbivory by rodents (Bullock 1991, Balgooyen and Waller 1995). In addition, deer and elk were frequently observed on the study site and their tracks and scat were noted near experimental plots.

One growing season after installing the herbivore exclosures, plant size was significantly different between protected and unprotected treatments. Stem and currentyear branch lengths of protected plants were from 1.9 to 2.8 -fold greater than those of unprotected plants (Table 1). Average stem diameter was also greater for protected plants than unprotected plants. Differences in current-year branch lengths between protected and unprotected plots translated directly to differences in biomass and leaf area (Table 1). Individual stems on protected plots retained more current-year biomass by a factor of 4.7 , and leaf area by a factor of 2.5 , compared to stems on unprotected plots. No difference was found in average number of stems on plots or the number of new branches produced by stems on protected and unprotected plots in 1999. All stems produced an average of $5.3(\mathrm{SE}=0.2)$ new branches during the first growing season.

In 2000 , growing season precipitation (20.4 cm; March-September) was about $66 \%$ of the 91 -year average $(31.0 \mathrm{~cm}$; Western Regional Climate Center 2000) and both protected and unprotected buckbrush plants showed varying degrees of stem dieback. Forty-four percent of current-year branches were browsed on unprotected plots. Average total stem length on protected plots increased $(\mathrm{P}=$ 0.05 ) slightly from the previous year and

Table 1. Means (and standard errors) of buckbrush vegetative characteristics on plots protected from large herbivores and on unprotected plots in 1999 and 2000.

\begin{tabular}{|c|c|c|c|c|}
\hline \multirow[b]{2}{*}{ Variable } & \multicolumn{2}{|c|}{1999} & \multicolumn{2}{|c|}{2000} \\
\hline & Protected & Unprotected & Protected & Unprotected \\
\hline \multicolumn{5}{|l|}{ Stems } \\
\hline Number & $8.1(1.0)$ & $6.9(0.6)$ & $9.1(1.2)^{*}$ & $5.4(0.5)$ \\
\hline Length $(\mathrm{cm})$ & $24.1(0.8)^{* * 1}$ & $12.9(0.7)$ & $25.9(1.0)^{* *}$ & $11.2(0.8)$ \\
\hline Diameter $(\mathrm{mm})$ & $3.5(0.1) \dagger$ & $3.1(0.1)$ & $4.1(0.2)^{*}$ & $3.5(0.1)$ \\
\hline \multicolumn{5}{|l|}{ Current-Year Branches } \\
\hline Number & $5.3(0.3)$ & $5.3(0.3)$ & $15.3(1.5)^{* *}$ & $7.1(0.6)$ \\
\hline Length $(\mathrm{cm})$ & $13.1(0.4)^{* *}$ & $4.7(0.4)$ & $5.8(0.4)^{* *}$ & $2.5(0.2)$ \\
\hline Longest $(\mathrm{cm})$ & $19.5(0.6)^{* *}$ & $7.7(0.5)$ & $9.7(0.6)^{* *}$ & $4.5(0.4)$ \\
\hline Biomass (g) & $1.4(0.1)^{* *}$ & $0.3(<0.1)$ & $1.6(0.5)^{* *}$ & $0.2(<0.1)$ \\
\hline Leaf Area $\left(\mathrm{cm}^{2}\right)$ & $83.9(6.3)^{* *}$ & $33.5(3.3)$ & $129.7(26.1)^{* *}$ & $27.1(3.2)$ \\
\hline \multicolumn{5}{|l|}{ Plot } \\
\hline Sum Diameter $\left(\mathrm{mm} \mathrm{m}^{-2}\right)$ & $24.5(3.0)^{*}$ & $18.5(1.5)$ & $30.4(3.4)^{* *}$ & $17.1(1.5)$ \\
\hline Sum Current-Year Biomass $\left(\mathrm{g} \mathrm{m}^{-2}\right)$ & $8.1(0.9)^{* *}$ & $1.7(0.2)$ & $8.7(1.7)^{* *}$ & $0.7(<0.1)$ \\
\hline Sum Current-Year Leaf Area $\left(\mathrm{cm}^{2} \mathrm{~m}^{-2}\right)$ & $492.0(55.0)^{* *}$ & $177.5(16.3)$ & $739.1(95.1)^{* *}$ & $109.5(9.7)$ \\
\hline
\end{tabular}

Symbols indicate significant difference between treatments within years $\left(\dagger \mathrm{P}<0.10 ;{ }^{*} \mathrm{P}<0.05 ;{ }^{* *} \mathrm{P}<0.01\right)$ 
was significantly greater than that of unprotected plots, which decreased $(\mathrm{P}=$ 0.06) (Table 1). Similarly, average stem diameter was greater on protected plots than unprotected plots. Although currentyear branch lengths on both protected and unprotected plots decreased $(\mathrm{P}<0.001$ for both treatments) in 2000 from 1999 values, number of current-year branches increased $(\mathrm{P}<0.001$ and $\mathrm{P}=0.003$ for protected and unprotected plots, respectively). Average number of current-year branches produced by stems on protected plots nearly tripled from 1999 and was significantly greater than the number produced by stems on unprotected plots (Table 1). Both average length and length of the longest current-year branch were greater on protected plots than unprotected plots by a factor of 2 or greater. Individual stems on protected plots comprised significantly more current-year biomass than stems on unprotected plots by a factor of 8 (Table 1). Large differences also existed between protected and unprotected stems for current-year leaf area.

Average number of stems did not change significantly $(P=0.31)$ from 1999 to 2000 on protected plots, but decreased on unprotected plots $(\mathrm{P}=0.002)$. More stems of larger average diameter led to significantly greater sum stem diameter (sum of all stems on a plot) on protected plots in 2000 (Table 1). Similarly, sum current-year biomass on protected plots in 2000 did not change from 1999 ( $P=0.81)$, whereas biomass decreased significantly $(\mathrm{P}<0.001)$ on unprotected plots. In 2000, current-year biomass summed on protected plots was greater than that on unprotected plots by a factor of 12 (Table 1). Similar patterns existed between protected and unprotected plots for sum current-year leaf area (Table 1). Sum leaf area significantly increased $(\mathrm{P}=0.014)$ from 1999 to 2000 on protected plots but decreased $(\mathrm{P}<$ 0.001 ) on unprotected plots.

\section{Stem Morphology}

Herbivory of current-year branches on buckbrush stems led to noticeable differences in stem morphology. Stem heightdiameter ratios were significantly greater for plants on protected plots than for those on unprotected plots (Table 2). Stems within herbivore exclosures typically appeared long and drooping whereas stems exposed to herbivores were most often short and stubby in appearance. Although protected plants produced more current-year branches than unprotected plants in 2000 , the number of branches relative to stem length was significantly greater for stems on unprotected plants in both 1999 and 2000 (Table 2).

\section{Flower Production}

In June 1999, three months after exclosures were established, no difference in flower production was found between protected and unprotected buckbrush plots. Stems produced flowers on just 2 of 180 total plots (1.1\% overall).

In June 2000, flowering stems were found in a significantly greater proportion of protected plots $(55 \%)$ than unprotected plots $(8 \%)$. On average, $22 \%(\mathrm{SE}=3.6)$ of stems on protected plots produced flowers whereas $0.8 \%(\mathrm{SE}=0.4)$ of stems produced flowers on unprotected plots. In protected plots, up to 11 (maximum) stems produced flowers whereas no more than 1 stem flowered in any unprotected plot.

Stems (all pooled) that produced flowers tended to be larger and apparently older individuals (Fig. 2). No stems under $20 \mathrm{~cm}$ in length produced flowers and $85 \%$ of the flowering stems were greater than $30 \mathrm{~cm}$ in length. Similarly, $82 \%$ of the flowering stems were greater than $4 \mathrm{~mm}$ in diameter. No current-year stems flowered and more than $90 \%$ of the flowering stems had suberized bases (age classes 3 and 4). The mean number of inflorescences (panicles) produced per flowering stem was 7.3. Inflorescences were comprised of many individual flowers although these were not counted. An average of 2 branches per stem flowered; the maximum number of flowering branches was 9 per stem.

\section{Discussion}

Mule deer and Rocky Mountain elk appeared to be the primary large herbivores of buckbrush and caused significant reduction of current-year biomass in both
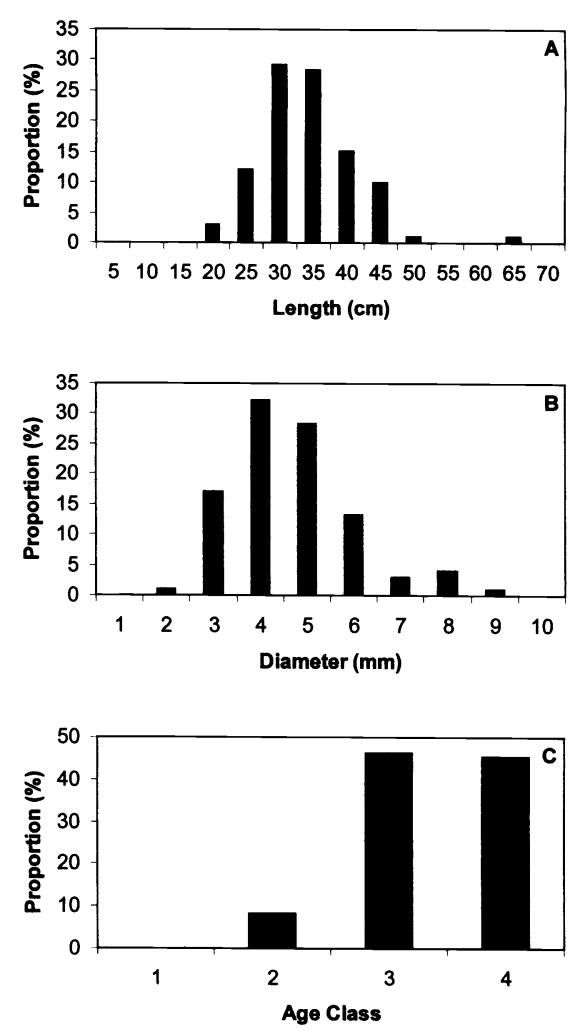

Fig. 2. Proportion of Ceanothus fendleri stems that produced flowers by length (A), diameter (B), and age class (C).

study years. Plants that were not protected from large herbivores had small, branchy stems, decreased aerial stem survival, and limited flowering compared with protected plants. Reduced flowering and stem survival could in turn lead to declines in local buckbrush abundance, affect community successional dynamics, and have indirect effects on other ecosystem components (Baines et al. 1994, Augustine and Frelich 1998). It is clear that herbivory by deer and elk is limiting development of understory structure. We did not examine interactions of herbivory and low-intensity fire, although prescribed burning is an important component of Southwest ponderosa pine restoration programs (Covington et al. 1997). Fire often leads to increases in vegetative and sexual regeneration through sprout production and seed germination, however, it can also increase palatability of

Table 2. Means (and standard errors) of morphological characteristics of buckbrush stems on protected and unprotected plots.

\begin{tabular}{|c|c|c|c|c|}
\hline \multirow[b]{2}{*}{ Variable } & \multicolumn{2}{|c|}{1999} & \multicolumn{2}{|c|}{2000} \\
\hline & $\overline{\text { Protected }}$ & Unprotected & Protected & Unprotected \\
\hline Height-Diameter Ratio $\left(\mathrm{cm} \mathrm{cm}^{-1}\right)$ & $73.5(1.9)^{* * 1}$ & $42.3(1.8)$ & $68.3(2.1)^{* *}$ & $32.6(1.8)$ \\
\hline Branchiness $^{2}\left(\mathrm{~N} \mathrm{~cm}^{-1}\right)$ & $0.2(<0.1)^{* *}$ & $0.4(<0.1)$ & $0.5(<0.1)^{*}$ & $0.7(<0.1)$ \\
\hline
\end{tabular}

${ }^{1}$ Symbols indicate significant difference between treatments within years $(* \mathrm{P}<0.05 ; * * \mathrm{P}<0.01)$

${ }^{2}$ Branchiness $=$ Number Current-year Branches $\div$ Stem Length 
plant tissues and create conditions that attract herbivores (Whelan 1995). Our results indicate that deer and elk herbivory after forest thinning should be considered an important constraint to the ecological restoration of these ecosystems.

Intensity of deer and elk herbivory on buckbrush and other species varies with season, site conditions, and ungulate population characteristics (Reynolds 1962, Patton 1974, Urness et al. 1975, Furniss et al. 1978, Allen 1996, Throop and Fay 1999). For example, Urness et al. (1975) found that buckbrush comprised up to $6.9 \%$ of mule deer summer diet and was a consistently important browse species throughout the year at Beaver Creek, a site located around $55 \mathrm{~km}$ south of ours. Other woody species preferred by mule deer at Beaver Creek were Gambel oak (Quercus gambelii Nutt.), mountain mahogany (Cercocarpus breviflorus Gray), and Utah serviceberry (Amelanchier utahensis Koehne). These species are not commonly found on our study site and thus preference for buckbrush may be greater at Fort Valley than that reported by Urness et al. (1975). Allen (1996) noted severe browsing of buckbrush 15 years after an extensive wildfire in New Mexico and related intensity of herbivory to a dramatic elk population increase. Patton (1974) found that mule deer use increased in ponderosa pine forests after overstory thinning. Thus, deer and elk may have been attracted to the open conditions created by forest thinning treatments in our study.

Under conditions that stimulate flower production or enhance plant growth, herbivory may positively contribute to ecological restoration goals by providing resource richness and abundance for various organisms in the food web and enhancing ecosystem function (Jackson et al. 1995). Paige and Whitham (1987) reported increased flower production after experimental clipping as well as natural herbivory by deer and elk for a northern Arizona forb, scarlet gilia (Ipomopsis aggregata (Pursh) V. Grant). Similarly, Throop and Fay (1999) found that browsed New Jersey tea (Ceanothus herbaceous Raf. var. pubescens (T. \& G.) Shinners) produced a greater number of inflorescences than unbrowsed plants on a tallgrass prairie site. In contrast, Stein et al. (1992) noted that elk completely consumed arroyo willow (Salix lasiolepis Benth.) resprouts after experimental burning in northern Arizona. Similarly, Strohmeyer and Maschinski (1996) reported both wild and domestic herbivores reduced total shoot length and number of branches of Arizona willow (Salix arizonica Dorn). Intense deer and elk herbivory can limit production of flowers, seeds, and vegetative regeneration of various plant species in other western ecosystems (DeByle 1985, Dunlap 1988, Mitchell and Freeman 1993, Hoffman and Wambolt 1996, Kay 1997, Opperman and Merenlender 2000). In our study, buckbrush flowers were observed on less than $10 \%$ of the unprotected plots. Limiting flower production may affect populations of species dependent on the reproductive structures of buckbrush (Huffman 2002). This suggests that ungulate herbivory can affect diversity and composition of invertebrate communities through direct competition for resources and "knock-on" effects occurring from changes in microclimate or predator-prey relationships (Baines et al. 1994, Rambo and Faeth 1999, Rooney 2001, Stewart 2001).

Further research is needed to explore the roles of wild ungulate herbivory in conservation and ecological restoration of Southwest ponderosa pine ecosystems. Current understanding of presettlement conditions-attributes that provide baselines to guide ecological restoration - is greatest for overstory characteristics and fire regimes (Covington and Moore 1994a, Covington et al. 1997, Fulé et al. 1997, Mast et al. 1999). Little is known regarding presettlement population dynamics and spatial distribution of large herbivores or the range of historical variability for their effects in Southwest forest ecosystems. On some landscapes, including that of our study area, elk are thought to be more abundant and distributed more evenly than they were for possibly the last 800 years (Allen 1996, Truett 1996, Kay 1997). Indeed, ungulate herbivory in combination with forest structural changes appears to be exacerbating conservation problems in these ecosystems. For ecological restoration activities that seek to reestablish ecosystem integrity and function, it is important to understand evolutionary environments of native species and emulate historical conditions of landscapescale processes that include herbivory by large, wild ungulates.

\section{Literature Cited}

Allen, C.D. 1996. Elk response to the La Mesa fire and current status in the Jemez mountains, p.179-195. In: Allen, C.D. (ed.), Proceedings of the $2^{\text {nd }}$ La Mesa Fire Symp.. USDA Forest. Serv. Gen. Tech. Rep. RMGTR-286.
Anderson, R.C. and O.L. Loucks. 1979. White-tail deer (Odocoileus virginianus) influence on structure and composition of Tsuga canadensis forests. J. Appl. Ecol. 16:855-861.

Arnold, J.F. 1950. Changes in ponderosa pine bunchgrass ranges in northern Arizona resulting from pine regeneration and grazing. J. Forest. 48:118-126.

Augustine, D.J. and L.E. Frelich. 1998. Effects of white-tailed deer on populations of an understory forb in fragmented deciduous forests. Conserv. Biol. 12:995-1004.

Augustine, D.J. and S.J. Mc Naughton. 1998. Ungulate effects on the functional species composition of plant communities: herbivore selectivity and plant tolerance. J. Wildl. Manage. 62:1165-1183.

Baines, D., R.B. Sage, and M.M. Baines. 1994. The implications of red deer grazing to ground vegetation and invertebrate communities of Scottish native pinewoods. J. Appl. Ecol. 31:776-783.

Balgooyen, C.P. and D.M. Waller. 1995. The use of Clintonia borealis and other indicators to gauge impacts of white-tailed deer on plant communities in Northern Wisconsin, USA. Nat. Area J. 15:308-318.

Biondi, F. 1996. Decadal-scale dynamics at the Gus Pearson Natural Area: evidence for inverse (a) symmetric competition? Can. J. Forest Res. 26:1397-1406.

Bullock, S.H. 1991. Herbivory and the demography of the chaparral shrub Ceanothus greggii (Rhamnaceae). Madroño 38:63-72.

Conard, S.G., A.E. Jaramillo, K. Cromack Jr., and S. Rose. 1985. The role of the genus Ceanothus in western forest ecosystems. USDA For. Serv. Gen. Tech. Rep. PNW-182.

Covington, W.W. and M.M. Moore. 1994a. Southwestern ponderosa forest structure and resource conditions: changes since EuroAmerican settlement. J. Forest. 92:39-47.

Covington, W.W. and M.M. Moore. 1994b. Postsettlement changes in natural fire regimes and forest structure: ecological restoration of old-growth ponderosa pine forests. J. Sustain. For. 2:153-181.

Covington, W.W., P.Z. Fulé, M.M. Moore, S.C. Hart, T.E. Kolb, J.N. Mast, S.S. Sackett, and M.R. Wagner. 1997. Restoring ecosystem health in ponderosa pine forests of the southwest. J. Forest. 95:23-29.

DeByle, N.V. 1985. Animal impacts, p. 115-123. In: DeByle. N.V., and R.P. Winokur (eds.), Aspen: ecology and management in the western United States. USDA For. Serv. Gen. Tech. Rep. RM-119.

Dunlap, T.R. 1988. That Kaibab myth. J. Forest Hist. 32:60-68.

Epple, A.O. 1995. A field guide to the plants of Arizona. Falcon Press, Helena, Mont., USA.

Fulé, P.Z., W.W. Covington, and M.M. Moore. 1997. Determining reference conditions for ecosystem management of southwestern ponderosa pine forests. Ecol. Appl. 7:895-908 
Furniss, M.M., T.A. Leege, and R.J. Naskali. 1978. Insects that reduce redstem ceanothus seed production in Idaho, p. 335-358. In: Hyder, D.N. (ed), Proceedings of the first international rangeland congress. Soc. for Range Manage., Denver, Colo.

Hoffman, T.L. and C.L. Wambolt. 1996. Growth response of Wyoming big sagebrush to heavy browsing by wild ungulates, $\mathrm{p}$. 242-245. In: Barrow, J.R., E.D. McArthur, R.E. Sosebee, R.J. Tausch (comps.), Proc.: Shrubland ecosystem dynamics in a changing environment. USDA Forest. Serv. Gen. Tech. Rep. INT-GTR-338.

Huffman, D.W. 2002. A seed chalcid (Eurytoma squamosa Bugbee) parasitizes buckbrush (Ceanothus fendleri Gray) seeds in a ponderosa pine forest of Arizona. West. N. Amer. Naturalist 62:474-478.

Jackson, L.L., N. Lopoukhine, and D. Hillyard. 1995. Commentary ecological restoration: a definition and comments. Restor. Ecol. 3:71-75.

Kay, C.E. 1997. Is aspen doomed? J. Forest. 95:4-11.

Kolb, T.E., M.R. Wagner, and W.W. Covington. 1994. Concepts of forest health. J. Forest. 92:10-15.

Mast, J.N., P.Z. Fulé, M.M. Moore, W.W. Covington, and A.E.M. Waltz. 1999. Restoration of presettlement age structure of an Arizona ponderosa pine forest. Ecol. Appl. 9:228-239.

Mitchell, J.E. and D.R. Freeman. 1993. Wildlife-livestock-fire interactions on the North Kaibab: A historical review. USDA For. Serv. Gen. Tech. Rep. RM-222.

Moore, M.M., W.W. Covington, and P.Z. Fulé. 1999. Reference conditions and ecological restoration: a southwestern ponderosa pine perspective. Ecol. Appl. 9:1266-1277.
Naiman, R.J. 1988. Animal influences on ecosystem dynamics (Large animals are more than passive components of ecological systems). Biosci. 38:750-752.

Opperman, J.J. and A.M. Merenlender. 2000. Deer herbivory as an ecological constraint to restoration of degraded riparian corridors. Restoration Ecol. 8:41-47.

Paige, K.N. and T.G. Whitham. 1987. Overcompensation in response to mammalian herbivory: the advantage of being eaten. Amer. Nat. 129:407-416.

Patton, D.R. 1974. Patch cutting increases deer and elk use of a pine forest in Arizona. J. Forest. 72:764-766.

Rambo, J.L. and S.H. Faeth. 1999. Effect of vertebrate grazing on plant and insect community structure. Conserv. Biol. 13:1047-1054.

Reynolds, H.G. 1962. Effect of logging on understory vegetation and deer use in a ponderosa pine forest of Arizona. USDA Forest. Serv. Res. Note 80.

Rooney, T.P. 2001. Deer impacts on forest ecosystems: a North American perspective. Forestry 74:201-208.

Rosenthal, J.P. and P.M. Kotanen. 1994. Terrestrial plant tolerance to herbivory. Trends Ecol. Evolut. 9:145-148.

Savage, M., P.M. Brown, and J. Feddema. 1996. The role of climate in a pine forest regeneration pulse in the southwestern United States. Ecosc. 3:310-318.

Stein, S.J., P.W. Price, W.G. Abrahamson, and C.F. Sacchi. 1992. The effect of fire on stimulating willow regrowth and subsequent attack by grasshoppers and elk. Oikos 65:190-196.

Stewart, A.J.A. 2001. The impact of deer on lowland woodland invertebrates: a review of the evidence and priorities for future research. Forestry 74:259-270.
Story, M.T. 1974. Nitrogen fixation by Ceanothus fendleri and Lupinus argenteus as a function of parent material and vegetal cover. M.S. Thesis. Univ. of Arizona, Tucson, Ariz.

Strohmeyer, S. and J. Maschinski. 1996. Cattle and elk herbivory on Arizona willow (Salix arizonica), p. 187-192. In: Maschinski, J., H.D. Hammond, and L. Holter (tech. coords.), Southwestern rare and endangered plants: Proceed. of the second conference. USDA For. Serv. Gen. Tech. Rep. RM-GTR-283.

Suzuki, K., H. Suzuki, D. Binkley, and T. Stohlgren. 1999. Aspen regeneration in the Colorado Front Range: differences at local and landscape scales. Landscape Ecol. 14:231-237.

Throop, H.L. and P.A. Fay. 1999. Effects of fire, browsers, and gallers on New Jersey tea (Ceanothus herbaceous) growth and reproduction. Amer. Midl. Nat. 141:51-58.

Truett, J. 1996. Bison and elk in the American Southwest: in search of the pristine. Environ. Manage. 20:195-206.

Urness, P.J., D.J. Neff, and R.K. Watkins. 1975. Nutritive value of mule deer forages on ponderosa pine summer range in Arizona. USDA For. Serv. Res. Note RM-304.

Vose, J.M. and A.S. White. 1987. Processes of understory seedling recruitment 1 year after prescribed fire in an Arizona ponderosa pine community. Can. J. Bot. 65:2280-2290.

Western Regional Climate Center. 2000. Western U.S. historical climate summaries. Flagstaff Airport, Flagstaff, Ariz. http://www.wrcc.dri.edu/climsum.html.

Whelan, R.J. 1995. The ecology of fire. Cambridge Univ. Press, Cambridge, UK. 